\title{
Nutrient Profiling of Tropical Soybean (Glycine Max) Core Collection
}

By Tonny Obua, Julius P. Sserumaga, Fredrick Nganga, Phineas Tukamuhabwa, Thomas L. Odong, Josiah Mutuku \& Nasser Yao

Abstract- Soybean (Glycine max (L.) Merrill) is a highly nutritious legume with enormous potential to improve dietary quality for humans and livestock. However, the development of varieties with improved nutritional traits has been affected by the negative correlation that exists among the different traits and the high cost of the phenotypic assessment. The objectives of this study were: (1) to quantify the total protein, total oil and fatty acids of 52 soybean genotypes from different sources, (2) to identify correlations among total protein, total oil content and fatty acids. The total protein content was determined using the Modified Folin-Lowry Method. In contrast, the total oil and fatty acids methyl esters were determined using the chloroform/methanol gravimetric method and Gas Chromatography-Mass Spectrometry. The analysis of variance revealed that the studied traits varied significantly depending on genotypes and origin.

Keywords: food composition, total protein, total oil content, palmitic acid, stearic acid, oleic acid, linoleic acid.

GJSFR-D Classification: FOR Code: 860799

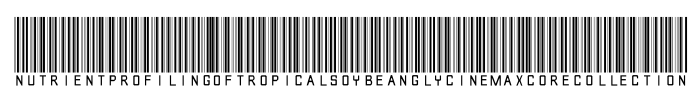

Strictly as per the compliance and regulations of:

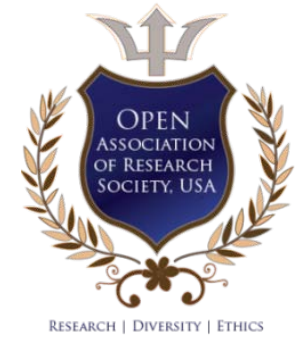

(C) 2020. Tonny Obua, Julius P. Sserumaga, Fredrick Nganga, Phineas Tukamuhabwa, Thomas L. Odong, Josiah Mutuku \& Nasser Yao. This is a research/review paper, distributed under the terms of the Creative Commons Attribution 4.0 Generic License https://creativecommons.org/licenses/by/4.0/), permitting all commercial use, distribution, and reproduction in any medium, provided the original work is properly cited. 


\title{
Nutrient Profiling of Tropical Soybean (Glycine Max) Core Collection
}

\author{
Tonny Obua ${ }^{\alpha}$, Julius P. Sserumaga ${ }^{\sigma}$, Fredrick Nganga ${ }^{\rho}$, Phineas Tukamuhabwa ${ }^{\omega}$, Thomas L. Odong ${ }^{*}$, \\ Josiah Mutuku ${ }^{\S} \&$ Nasser Yao ${ }^{x}$
}

Abstract- Soybean (Glycine max (L.) Merrill) is a highly nutritious legume with enormous potential to improve dietary quality for humans and livestock. However, the development of varieties with improved nutritional traits has been affected by the negative correlation that exists among the different traits and the high cost of the phenotypic assessment. The objectives of this study were: (1) to quantify the total protein, total oil and fatty acids of 52 soybean genotypes from different sources, (2) to identify correlations among total protein, total oil content and fatty acids. The total protein content was determined using the Modified Folin-Lowry Method. In contrast, the total oil and fatty acids methyl esters were determined using the chloroform/methanol gravimetric method and Gas Chromatography-Mass Spectrometry. The analysis of variance revealed that the studied traits varied significantly depending on genotypes and origin. Total protein content ranged from $30.07 \%$ to $50.40 \%$, while total oil content ranged from $14.94 \%$ to $23.48 \%$. Total oil content varied significantly between origins with genotypes from the USA having the highest mean of $20.43 \%$, while those from AVRDC had the lowest mean of $18.32 \%$. Palmitic acid (16:0) content ranged from $10.58 \%$ to $21.18 \% ; 4.93 \%$ to $22.20 \%$ for stearic acid (18:0), $22.69 \%$ to $39.95 \%$ for oleic acid (18:1) and $30.60 \%$ to $51.72 \%$ for linoleic acid (18:2). Genotypes from Uganda had the highest percentages of oleic acid, followed by genotypes from Japan. Six negative and three positive correlations were found to be significant in the current study further. The current study identified soybean genotypes with elevated protein and oil content above the average that can be used to improve the nutritional properties of soybean in Uganda and across the East African region hence boosting the soybean industry.

Keywords: food composition, total protein, total oil content, palmitic acid, stearic acid, oleic acid, linoleic acid.

\section{INTRODUCTION}

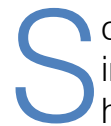
oybean (Glycine max (L.) Merrill) has become an important ingredient in the diets of both the human and livestock due to its high nutritional value and low cost (Friedman and Brandon 2001; Singh et al. 2008; Drago et al. 2011). The total world soybean production is estimated at 348.7 million metric tons

Author $\alpha \omega ¥$ : College of Agricultural and Environmental Sciences, Makerere University Kampala, P. O. Box 7062 Kampala, Uganda. e-mail: obuatonny@gmail.com

Author o: National Agricultural Research Organization; National Livestock Resources Research Institute, Nakyesasa, 5704, Kampala, Uganda. Author $\rho \S \chi$ : Biosciences eastern and central Africa - International Livestock Research Institute, P.O Box 30709 Nairobi, 00100 Kenya.
(MT). The world's leading producer is the USA, which produces about $35 \%$ of the world soybean (123.7 million MT). Brazil is second with $34 \%$ of soybean produced (117.9 million MT) while Argentina is third with $11 \%$ (37.8 million MT), and China is fourth with $4 \%$ (14.2 million MT). The remaining countries account for $16 \%$ (55.2 million MT) of the global soybean output (FAO 2018). In Africa, total soybean production rose from 1.4 million MT in 2008 to 3.6 million MT in 2018, representing $1.0 \%$ of the world production. The three leading African countries in soybean production are South Africa $(1,316,000 \mathrm{MT})$, Nigeria $(730,000 \mathrm{MT})$, and Zambia $(351,416 \mathrm{MT})$ (FAO 2018). Soybean grains contain about $40 \%$ protein, $20 \%$ oil, an optimal supply of protein,and high-calorie value (Singh et al., 2008). Additionally, soybean oil is composed of approximately $16 \%$ saturated fatty acids (palmitic [C16:0] and stearic [C18:0]), 24\% monounsaturated fatty acids (oleic [C18:1]), and 60\% polyunsaturated fatty acids (linoleic [C18:2] and linolenic [C18:3]) (Drago et al. 2011).

The processing capacity for soybean has significantly increased in Uganda and across the East African region that has been triggered by the growing interest of the farmers to grow the crop as a main source of cash because of the available superior varieties(Tukamuhabwa et al. 2019). These established processing plants make different food and feed products. However most consumers are interested in soy-based food products with improved protein and oil content to meet special food applications (Singh et al. 2008; Miladinovic et al. 2011). In the past decade, the key focus for most soybean breeding programs in Tropical Africa has been on improvement of traits such as yield, resistance to pod shattering and lodging, high pod clearance, resistance to pests and diseases. In contrast, the traits related to seed composition have received very little attention (Tukamuhabwa et al. 2019; Tukamuhabwa and Oloka 2016; Bashaasha 1992). Moreover, the development of varieties with improved nutritional properties has been further affected by the negative correlation that exists among the different traits. For example, several studies have reported a significant negative correlation between oleic acid and palmitic acid (Qin et al. 2014; Ahire 2012; Alt et al. 2005; Rebetzke et al. 2001). Similarly total oil has been reported to exhibit a strong negative correlation with oleic acid (Rani et al. 2007; Bachlava et al. 2008). 
Likewise, a negative correlation between oil and protein has also been reported in several studies (Marega et al. 2001; Qin et al. 2014). Therefore during the selection of soybean genotypes for a particular food application or breeding program, it is fundamental to understand the relationships that exist among these quality attributes. However, these relationships have not been widely assessed on tropical soybean germplasm. Additionally one of the requirements in any successful plant breeding program is to create variability to make selection. One way of creating variability in a breeding program is the importation of germplasm from other sources. For example, in Uganda, a lot of soybean germplasm has been introduced from other parts of the world to increase the genetic base. However, there is inadequate information on the nutritional properties of these introduced germplasm.

Knowledge of the relationship among the different nutritional traits in soybean would be very vital in developing soybean varieties with improved nutritional properties. Therefore the objectives of this study were: (1) to quantify the total protein, total oil and fatty acids of 52 soybean genotypes from different sources, (2) to identify correlations among total protein, total oil content, and fatty acids. Therefore the findings from this study could provide an opportunity to develop soybean varieties with improved nutritional traits.

\section{il. Materials and Methods}

\section{a) Plant Materials and Sample Preparation}

Fifty-two soybean genotypes were planted at the National Crops Resources Research Institute (NaCRRI), located in Central Uganda in the first season of 2016. The soybean genotypes were planted in one location to minimize the effect of the environment on the chemical composition of the soybean grain. The 52 soybean genotypes were planted in an alpha lattice design with three replicates. The plot size was $5 \mathrm{~m}$ long with a spacing of $60 \mathrm{~cm} \times 5 \mathrm{~cm}$. The grain from each plot was harvested and sun-dried to below 10\% moisture content. The seed samples for each genotype were divided into three replicates and about $300 \mathrm{~g}$ ground through a $2 \mathrm{~mm}$ screen using Cyclotec ${ }^{\mathrm{TM}} 1093$ mill (FOSS, 2011). The milled samples were stored in the cold room at a temperature $-4^{\circ} \mathrm{C}$ at BecA - ILRI Hub, Nairobi Kenya, where all the subsequent analysis was performed.

\section{b) Total Protein Content}

Total Protein content was determined using the Modified Folin-Lowry Method (Lowry et al. 1951). 100 $\mathrm{mg}$ of the milled samples were weighed in duplicate into $25 \mathrm{~mL}$ culture tubes. $5 \mathrm{ml}$ 5\% sodium dodecyl sulphate (SDS) was added, vortexed, and left to stand for 2 hours at room temperature and centrifuged at $2000 \mathrm{ppm}$ for 10 min. $50 \mu \mathrm{l}$ aliquot was taken and diluted with $950 \mu \mathrm{l}$ of water and made to $1000 \mu \mathrm{l}$ in separate culture tubes.
$100 \mathrm{ul}$ aliquot of the diluted extract was taken for analysis. Blank (100 $\mu \mathrm{l}$ of distilled water), standards (0, $100,200,300,400,500 \mu \mathrm{l}$ of Bovine serum albumin) and samples $(100 \mu \mathrm{l})$ were pipetted into glass culture tubes, and all made to $1000 \mu \mathrm{l}$.

$1 \mathrm{ml}$ Reagent A ( 0.4 volumes of water, 1 volume CTC reagent, 1.6 volumes of $5 \%$ SDS and 1 volume of $0.8 \mathrm{M} \mathrm{NaOH}$ ) was then added to each of the tubes and immediately vortexed; at 20 seconds interval. $500 \mu \mathrm{l}$ of Reagent B (1 volume of Folin-Ciocalteu phenol reagent, 2 Aldrich 9252, and 5 volumes of distilled water) was added to each tube and immediately vortexed and left to stand for 30 minutes for color development. An ultraviolet-visible spectrophotometer was used to measure the absorbance of the standards and samples versus the blank at a wavelength setting of $750 \mathrm{~nm}$. The absorbance values of the standards versus their corresponding protein concentrations were plotted to prepare a calibration curve, and the protein concentration of the samples were determined.

The total protein content in the residue was calculated using the formulae:

$$
\text { Total Protein }(\mathrm{g} / 100 \mathrm{~g})=\frac{\mathrm{C} \times 100 \mathrm{XDF}}{10^{6} \times \mathrm{W}}
$$

Where;

$\mathrm{C}=$ Concentration obtained from the calibration in $\mu \mathrm{g} / \mathrm{ml}$ $100=$ Conversion factor to report results in $\mathrm{g} / 100 \mathrm{~g}$

$\mathrm{DF}=$ Total dilution factor (1000)

$10^{6}=$ Conversion from $\mu \mathrm{g}$ to $\mathrm{g}$

$W=$ Weight of the sample in grams

\section{c) Total Oil Content and Fatty Acid Profiling}

Total oil content was determined using the chloroform/methanol gravimetric method (Bligh and Dyer, 1959). $2.0 \mathrm{~g}$ of the milled sample for each soybean genotype was weighed in duplicate into $50 \mathrm{~mL}$ culture tubes $\left(W_{1}\right)$. $32 \mathrm{ml}$ of Clarase solution was added, the tubes capped and gently shaken until the sample was well mixed with the enzyme solution. The sample was incubated for one hour in a $45^{\circ} \mathrm{C}$ water bath while gently mixing by inversion after every 20 minutes. All the extract was transferred to a $250 \mathrm{ml}$ polypropylene bottle, capped and centrifuged at $2000 \mathrm{rpm}$ for 15 minutes to clarify the chloroform. The top aqueous phase was carefully removed and discarded with a tap aspirator pump leaving a 2-4 mm thick layer on the chloroform. A hole was cautiously broken into the surface crust with a glass rod, and $20.0 \mathrm{ml}$ of the chloroform extract was pipetted into a pre-weighed $50 \mathrm{ml}$ beaker $\left(\mathrm{W}_{2}\right)$. Further, a $20 \mathrm{ml}$ aliquot of the chloroform extract was taken and stored at $-20^{\circ} \mathrm{C}$ for fatty acids methyl esters (FAMES) analysis with Gas Chromatography - Mass Spectrometry (GC - MS). The solution was evaporated to dryness by leaving it overnight in a fume hood; the beaker placed in an oven at $102^{\circ} \mathrm{C}$ for 30 minutes, 
removed and cooled in an evacuated desiccator for 1 hour. The beaker and the total oil was weighed on a microbalance to the nearest $0.1 \mathrm{mg}\left(\mathrm{W}_{3}\right)$.

The total oil in the residue was calculated using the formulae:

$$
\text { Total oil }(\mathrm{g} / 100 \mathrm{~g})=\frac{\left(W_{3}\right)-\left(W_{2}\right) \times 100 \times 4}{\left(W_{1}\right)}
$$

Where; $W_{1}$ - Sample weight (g)

$W_{2}$ - Weight of beaker

$W_{3}$ - Weight of beaker + total oil

FAMES were analyzed using a DB- 5 column, on an HP 5890 Series II GC equipped with an HP 7673 auto sampler (Hewlett Packard, Sunnydale, CA). Peak areas were recorded using Chem Station software (Hewlett Packard, Sunnydale, CA). Identification of individual FAMES was performed by calculating the Kovats linear retention index. The linear retention index was subsequently compared with obtained values from the National Institute of Standards and Technology (NIST) and Pherobase databases in cases where standards were absent. Quantification of individual FAMES was performed by the area percent method.

d) Statistical Analysis

Statistical differences among the different soybean genotypes were estimated from ANOVA test at the $5 \%$ level $(P=0.05)$ of significance for all the parameters evaluated, using Genstat, $13^{\text {th }}$ Edition (Payne et al. 2010). Whenever ANOVA indicated a significant difference, a pairwise comparison of mean by Least Significant Difference test (LSD) was carried out. Correlation analysis was performed using the corrplot package for graphical display using the Pearson method.

\section{Results}

\section{a) Total Protein Content}

Genotypes from Japan had the highest protein content of $43.47 \%$, followed by the USA $(42.42 \%)$, and genotypes from Uganda had the lowest protein content of $40.19 \%$ (Table 1). Genotypes Sline 5.18, BSPS 48A-8 and BSPS 48A-27-1 had the highest protein content of $50.40 \%, 48.88 \%$, and $48.08 \%$ respectively (Table 2 ). On the other hand, NIIXGC 17.3 and Nam II had the lowest protein content of $30.07 \%$ and $35.57 \%$ (Table 2).

\section{b) Total Oil Content}

Genotypes from the USA had the highest oil content of $20.43 \%$, followed by Seedco $(20.11 \%)$ and AVRDC had the lowest (18.32\%) (Table 1). G32B, Roan and AGS 338 had the highest oil content of $23.48 \%$, $23.47 \%$ and $23.26 \%$ respectively while Signal had the lowest content of $14.94 \%$ (Table 2).

\section{c) Fatty Acids Content}

Soybean genotypes from Uganda had the highest oleic fatty acid content (33.85\%), followed by genotypes from Japan (33.17\%), and Seedco had the lowest (30.68\%) (Table 1). Genotypes BSPS 48A-25, G7955 and BSPS 48A-5 had the highest oleic fatty acid content of $39.95 \%, 38.95 \%$, and $38.66 \%$ respectively while NG $14.1-16$ had the lowest content of $22.69 \%$ (Table 2).

Genotypes from the USA had the highest palmitic acid content of $15.00 \%$, followed by AVRDC (14.71\%), and SEEDCO had the lowest (13.23\%) (Table 1).Genotypes Nam II, Siesta, and Namsoy 3 had the highest palmitic acid content of $21.18 \%, 20.18 \%$ and 19.68\%, respectively (Table 2).On the other hand, G7955 and K-Local had the lowest palmitic acid content of $10.58 \%$ and $10.95 \%$, respectively (Table 2 ).

For stearic acid content, significant differences were observed among both genotypes and origin of the genotypes (Table 1). Genotypes from AVRDC had the highest stearic acid content of $9.05 \%$, while those from Japan were the lowest (7.42\%). Genotypes NG 14.1-16, AVRDC SRE-B-11-13, and Sequel had the highest stearic acid content of $16.76 \%, 15.58 \%$, and $14.57 \%$ respectively, while Sline 16.2 had the lowest content of 4.93\% (Table 2). Additionally, Saga had the highest linoleic acid content of $51.72 \%$, while Maksoy $5 \mathrm{~N}$ had the lowest content of $30.60 \%$ (Table 2). 
Table 1: Variation of Total Protein (\%), Total Oil (\%) and Fatty Acids (\%) of soybean genotypes from different origins

\begin{tabular}{|c|c|c|c|c|c|c|c|}
\hline $\begin{array}{l}\text { Origin and No. } \\
\text { of genotypes }\end{array}$ & & Total Protein & Total Oil & Oleic Acid & Palmitic Acid & Stearic Acid & Linoleic Acid \\
\hline \multirow{4}{*}{$\begin{array}{c}\text { AVRDC } \\
6\end{array}$} & Mean & 41.05 ** & $18.32^{* \star *}$ & 32.40 & 14.71 * & $9.05^{* * *}$ & 43.64 \\
\hline & Range & $36.88-46.06$ & $11.59-23.27$ & $22.94-38.35$ & $11.14-19.12$ & $5.46-15.38$ & $36.59-48.60$ \\
\hline & $\% c v$ & 9.9 & 6.9 & 15.8 & 14.84 & 14.22 & 8.16 \\
\hline & $\mathrm{Se}$ & 4.052 & 1.273 & 4.974 & 2.217 & 1.287 & 3.617 \\
\hline \multirow{4}{*}{$\begin{array}{l}\text { Japan } \\
\quad 6\end{array}$} & Mean & $43.47^{\star \star \star}$ & $18.73^{\star \star \star}$ & 33.17 * & 13.44 & 7.42 ** & $45.52^{\star}$ \\
\hline & Range & $39.88-50.40$ & $15.35-20.65$ & $31.13-36.17$ & $11.91-13.31$ & $4.93-7.06$ & $35.69-48.66$ \\
\hline & $\% c v$ & 5.1 & 5.1 & 1.16 & 4.7 & 4.39 & 1.03 \\
\hline & Se & 2.199 & 0.948 & 0.3872 & 0.6164 & 0.299 & 0.4739 \\
\hline \multirow{4}{*}{$\begin{array}{c}\text { SEEDCO } \\
10\end{array}$} & Mean & 42.18 & $20.11 * * \star$ & 30.68 ** & 13.23 ** & $8.59 \star \star \star$ & 46.82 \\
\hline & Range & $37.93-44.88$ & $14.94-23.47$ & 22.68-36.79 & $10.47-20.39$ & $5.02-14.56$ & $40.47-53.19$ \\
\hline & $\% c v$ & 10.9 & 10 & 8.55 & 14.93 & 16.29 & 8.64 \\
\hline & $\mathrm{Se}$ & 4.589 & 2.004 & 2.632 & 2.026 & 1.388 & 4.017 \\
\hline \multirow{4}{*}{$\begin{array}{l}\text { UGANDA } \\
25\end{array}$} & Mean & $40.19^{\star \star \star}$ & $19.11^{\star \star \star}$ & $33.85^{\star \star \star}$ & $13.57^{\star \star \star}$ & $8.24^{\star \star \star}$ & $43.94^{\star \star \star}$ \\
\hline & Range & $30.07-48.88$ & $15.27-22.58$ & $22.70-39.66$ & $10.93-21.05$ & $4.94-16.75$ & $30.25-51.65$ \\
\hline & $\% c v$ & 16.8 & 8.7 & 9.23 & 10.56 & 30 & 4.26 \\
\hline & $\mathrm{Se}$ & 6.739 & 1.658 & 3.17 & 1.374 & 2.324 & 1.904 \\
\hline \multirow{4}{*}{$\begin{array}{c}\text { USA } \\
5\end{array}$} & Mean & 42.42 * & $20.43 * *$ & 31.69 ** & 15.00 & 8.70 * & 43.89 \\
\hline & Range & $36.1-44.68$ & $17.19-23.48$ & $26.83-35.31$ & $11.66-17.33$ & $5.74-12.02$ & $39.85-47.26$ \\
\hline & $\% c v$ & 10.1 & 6.9 & 0.91 & 20.42 & 8.83 & 9.58 \\
\hline & $\mathrm{Se}$ & 4.296 & 1.419 & 0.2866 & 2.955 & 0.7764 & 4.299 \\
\hline
\end{tabular}

${ }^{*},{ }^{* *}$ and ${ }^{* * *}$ indicate significance at $p \leq 0.05, p \leq 0.01$, and $p \leq 0.001$ respectively

Table 2: Composition of Total Protein (\%), Total Oil (\%) and Fatty Acids (\%) of soybean genotypes

\begin{tabular}{lcccccc}
\hline \multicolumn{1}{c}{ Genotypes } & $\begin{array}{c}\text { Total } \\
\text { Protein }\end{array}$ & Total Oil & $\begin{array}{c}\text { Oleic } \\
\text { Acid }\end{array}$ & $\begin{array}{c}\text { Palmitic } \\
\text { Acid }\end{array}$ & $\begin{array}{c}\text { Stearic } \\
\text { Acid }\end{array}$ & $\begin{array}{c}\text { Linoleic } \\
\text { Acid }\end{array}$ \\
\hline AGS 338 & 37.97 & 23.26 & 35.88 & 11.80 & 6.54 & 45.77 \\
AVRDC G2843B & 37.32 & 21.75 & 24.12 & 18.21 & 12.26 & 45.42 \\
AVRDC G7956 & 36.88 & 17.55 & 33.35 & 13.06 & 7.09 & 46.48 \\
AVRDC GC00138-29 & 41.43 & 17.96 & 32.74 & 15.20 & 9.17 & 42.90 \\
AVRDC GC84051-31-1 & 42.55 & 16.46 & 35.51 & 18.13 & 8.32 & 35.89 \\
AVRDC SRE-B-11-13 & 43.58 & 16.23 & 27.90 & 19.08 & 15.58 & 37.41 \\
BSPS 48A-25 & 37.11 & 17.61 & 39.95 & 11.65 & 8.41 & 39.97 \\
BSPS 48A-27-1 & 48.08 & 19.87 & 37.38 & 12.08 & 7.07 & 43.47 \\
BSPS 48A-3B & 37.84 & 19.30 & 37.56 & 11.84 & 6.54 & 44.06 \\
BSPS 48A-5 & 41.37 & 17.87 & 38.66 & 11.78 & 6.67 & 42.89 \\
BSPS 48A-8 & 48.88 & 17.59 & 32.64 & 15.44 & 13.23 & 38.54 \\
G32B & 44.68 & 23.48 & 26.49 & 16.58 & 12.15 & 44.28 \\
G42 & 43.87 & 17.19 & 33.67 & 14.51 & 7.56 & 43.84 \\
G45 & 36.10 & 18.27 & 35.53 & 11.51 & 5.84 & 47.11 \\
G7955 & 46.06 & 20.97 & 38.95 & 10.58 & 5.47 & 45.05 \\
Gazelle & 44.57 & 17.89 & 34.1 & 14.68 & 6.979 & 44.08 \\
K-Local & 39.89 & 18.94 & 32.26 & 10.95 & 5.167 & 51.63 \\
Kab 1 & 39.17 & 15.59 & 34.58 & 11.49 & 5.36 & 48.57 \\
\hline
\end{tabular}




\begin{tabular}{|c|c|c|c|c|c|c|}
\hline Kuntz & 39.88 & 22.24 & 30.65 & 16.76 & 9.01 & 41.65 \\
\hline Maksoy 2N & 43.86 & 22.58 & 28.88 & 18.38 & 13.57 & 34.86 \\
\hline Maksoy 4N & 45.32 & 21.34 & 36.32 & 13.43 & 10.01 & 39.50 \\
\hline Maksoy 5N & 40.11 & 15.27 & 37.63 & 17.72 & 11.46 & 30.60 \\
\hline MNG 12.4 & 35.86 & 19.85 & 34.49 & 12.63 & 8.54 & 44.36 \\
\hline Nam II & 35.57 & 20.91 & 23.94 & 21.18 & 14.14 & 40.71 \\
\hline Namsoy 3 & 40.68 & 17.54 & 25.78 & 19.68 & 13.13 & 37.41 \\
\hline$N G 14.1-16$ & 44.93 & 20.20 & 22.69 & 19.05 & 16.76 & 41.50 \\
\hline NGDT 4.11-4 & 37.66 & 21.00 & 37.04 & 13.14 & 8.03 & 41.79 \\
\hline NGDT 8.11-4 & 42.11 & 21.63 & 36.52 & 11.35 & 6.47 & 45.64 \\
\hline NII X GC 11.2 & 39.64 & 18.54 & 32.51 & 13.42 & 7.07 & 46.97 \\
\hline NII X GC 17.3 & 30.07 & 20.53 & 34.42 & 11.79 & 6.47 & 47.32 \\
\hline NII X GC 20.3 & 38.90 & 17.28 & 31.35 & 15.99 & 11.42 & 41.21 \\
\hline $\mathrm{NII} X \mathrm{GC} 28.2 \mathrm{~B}$ & 38.65 & 18.26 & 32.97 & 13.00 & 6.04 & 47.99 \\
\hline $\mathrm{NII} X \mathrm{GC} 30 \mathrm{~B}$ & 42.82 & 20.58 & 36.91 & 12.35 & 5.80 & 44.94 \\
\hline NII X GC 32.6 & 41.01 & 20.55 & 37.04 & 11.57 & 6.36 & 45.02 \\
\hline NII X GC 43.2 & 39.54 & 19.88 & 31.95 & 11.92 & 6.75 & 49.38 \\
\hline NII X GC 44.2 & 38.80 & 18.27 & 32.76 & 11.42 & 5.64 & 50.18 \\
\hline NII X GC 7.2 & 39.46 & 16.54 & 34.63 & 13.37 & 6.32 & 45.69 \\
\hline Roan & 43.84 & 23.47 & 34.32 & 11.45 & 6.49 & 47.71 \\
\hline Saga & 42.12 & 23.07 & 27.09 & 11.16 & 10.07 & 51.72 \\
\hline Saxon & 40.95 & 17.91 & 36.95 & 12.22 & 6.94 & 43.90 \\
\hline Sentinel & 37.93 & 15.81 & 33.50 & 11.45 & 5.47 & 49.57 \\
\hline Sequel & 40.27 & 19.92 & 26.13 & 17.42 & 14.57 & 40.00 \\
\hline Siesta & 43.42 & 22.79 & 25.86 & 20.18 & 12.62 & 41.34 \\
\hline Signal & 39.17 & 14.94 & 32.71 & 11.93 & 4.97 & 50.39 \\
\hline Sline 13.2A & 42.19 & 19.88 & 31.04 & 18.29 & 14.51 & 35.69 \\
\hline Sline 16.2 & 39.88 & 15.35 & 36.04 & 11.95 & 4.93 & 47.07 \\
\hline Sline 4.21 & 42.12 & 19.00 & 36.26 & 12.26 & 5.55 & 45.98 \\
\hline Sline 5.18 & 50.40 & 20.60 & 30.49 & 12.90 & 7.15 & 48.39 \\
\hline Sline 6.22 & 44.67 & 16.90 & 33.67 & 12.19 & 5.45 & 48.67 \\
\hline Sline 7.11 & 43.14 & 20.65 & 31.56 & 13.30 & 6.87 & 47.08 \\
\hline Soprano & 40.11 & 19.24 & 35.54 & 11.84 & 5.68 & 46.99 \\
\hline Squire & 44.88 & 22.66 & 22.82 & 11.28 & 11.96 & 49.44 \\
\hline Mean & 40.71 & 19.44 & 32.79 & 13.88 & 8.50 & 44.38 \\
\hline LSD & 9.33 & 2.82 & 3.28 & 3.32 & 3.09 & 3.72 \\
\hline CV\% & 14.30 & 9.00 & 6.10 & 14.60 & 22.20 & 5.10 \\
\hline
\end{tabular}

d) Correlation Analysis for Total Protein, Total Oil and Fatty Acids

A total of nine correlations were found to be significant; six negative and three positive (Figure 1). Negative correlations were found between palmitic acid/linoleic acid, stearic acid/linoleic acid, oleic acid/palmitic acid, oleic acid/stearic acid, oleic acid/total oil and oleic acid/total protein. The positive correlations were found between palmitic acid/stearic, stearic acid/total oil and total oil/total protein. 


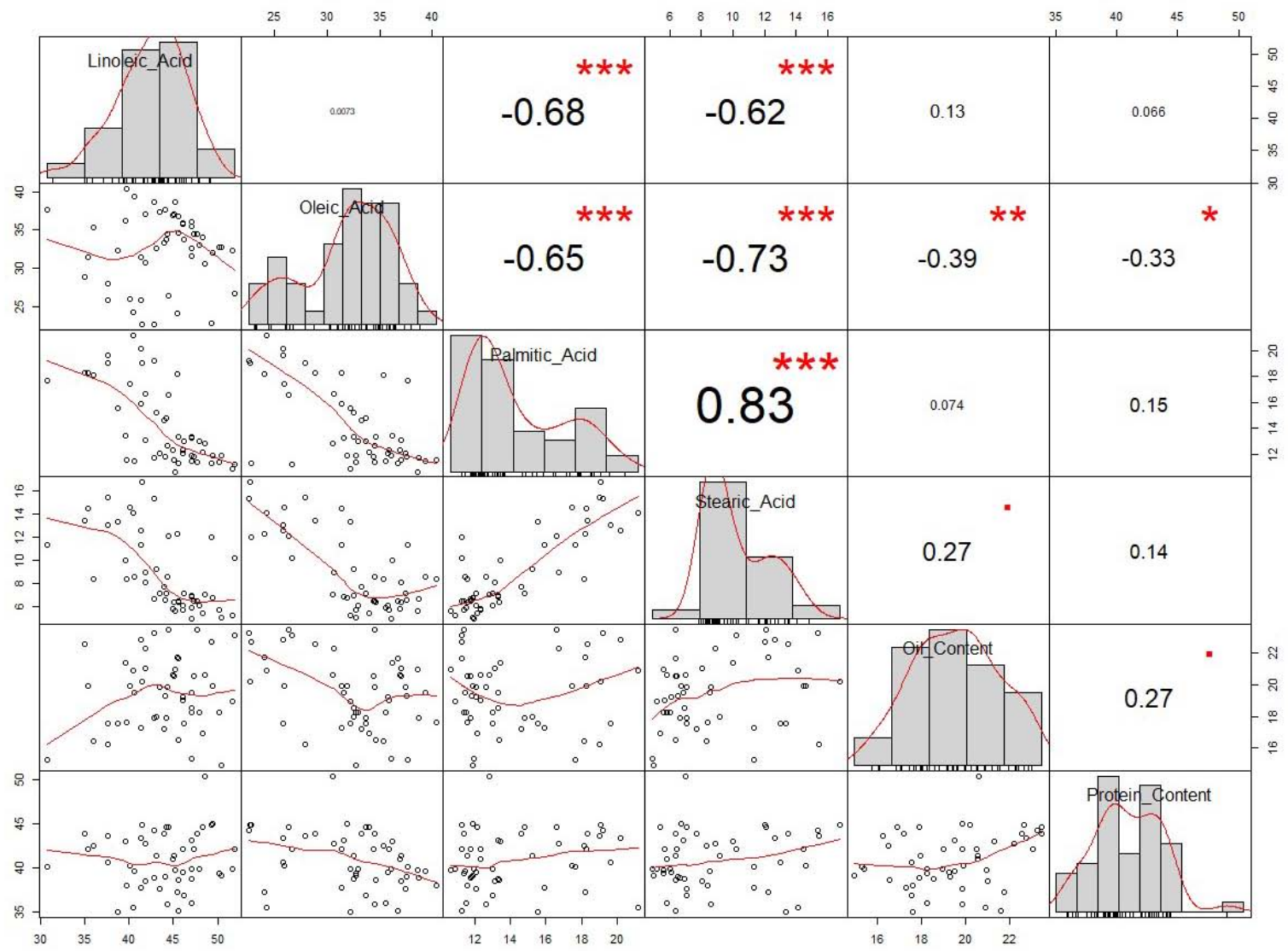

${ }^{*}, * *$ and ${ }^{* * *}$ indicate significance at $p \leq 0.05, p \leq 0.01$, and $p \leq 0.001$ respectively; values with $n$ s are not significant at $P<0.05$.

Figure 1: A Corrplot showing distribution and correlation between the different nutritional traits

\section{Discussion}

In this study, we used 52 soybean genotypes that were carefully selected based on origins from a core set of 504 accessions from five countries (USA, Japan, Taiwan, Zimbabwe and Uganda). We investigated the variability of different nutritional traits and correlations among these traits that were from different countries. High protein content has been one of the most key traits for most soybean improvement programs. The results of this study revealed that soybean genotypes from Japan had the highest protein content. The high protein content of genotypes from Japan is in agreement with a study conducted by Grieshop et al. (2001), who compared the nutritional properties of soybean from Brazil, China, and the USA and found out that soybean genotypes from China had the highest protein.

Similarly, Karr-Lilienthal et al. (2004) compared the nutritional composition of soybean grain and subsequent soybean meal from Argentina, Brazil, China, India, and the United States. This study reported that soybean from China had the highest protein content compared to the other four countries. Therefore in the current study, it is not surprising that soybean genotypes from Japan, which is geographically closer to China, had high protein content. The high oil content among genotypes from the USA also agrees with previous studies (Baize 1999; Grieshop et al. 2001) who reported that soybeans from the USA had higher oil content those soybeans from China. The high protein content in soybean genotypes from Japan and USA was high because of the extensive breeding for high protein and high consumption of soybean protein in these two countries (Fukushima 2011).

The proportion of palmitic acid observed in the current study was in general agreement with previous studies conducted on different soybean genotypes (Maestri et al. 1998; Cardinal et al. 2007; Rani et al. 2007; Bachlava et al. 2008; Ahire 2012). However, there were several soybean genotypes that showed an elevated proportion of palmitic acid that could be used for the development of high-palmitic soybean varieties. Soybean oil with high proportions of palmitic acid has industrial application for production of plastic fats like shortening and margarine (Fehr et al. 1998). For plastic fat to remain stable, it is desirable to have a fatty acid composition of about $15 \%$ or more of palmitic acid (Fehr et al. 1998). In the present study, palmitic acid showed a positive correlation with stearic acid that was in 
agreement with earlier reports (Stoltzfus et al. 2000; Rahman et al. 2003; Bachlava et al. 2008; Ahire 2012).

Further, the use of soybean oil having a relatively high content of saturated fatty acids (palmitic acid and stearic acid) allows the production of more desirable plastic fat. Palmitic acid averages approximately $11 \%$ of the total fatty acids, whereas stearic acid averages about $4 \%$ of total fatty acids present in conventional soybean oil. Additionally, it is highly desirable to develop soybean varieties having elevated palmitic acid and stearic acid contents to produce stable plastic fat. A separate study by Rahman et al. (2003) reported that palmitic acid and stearic acid are inherited independently; therefore, the trait of elevated saturated fatty acids in one genotype can be easily achieved by conventional breeding.

Furthermore, we also observed a significant negative correlation between palmitic acid and oleic acid. This negative correlation has been reported previously in several studies (Rebetzke et al. 2001; Qin et al. 2014; Ahire 2012; Alt et al. 2005). Qin et al. (2014) reported a significant negative correlation between oleic acid and palmitic acid. Ahire (2012) also detected a negative correlation between oleic acid and palmitic acid among selected mutants from soybean variety MACS 450. Alt et al. (2005) showed that oleic acid of 88 F2:3 lines was negatively correlated with palmitic acid $(r=-0.470)$.

The negative correlation between oleic acid and the saturated fatty acids (palmitic and stearic) coupled with a positive correlation between palmitic acid and stearic acid offer the opportunity to develop soybean varieties with improved oil quality. In the present study, results indicated that selection for higher oleic acid results in lower palmitic and stearic acids hence improvement in the quality of the soybean oil (Pham 2011; Qin et al. 2014). Oleic fatty acid is a monounsaturated fatty acid that can improve the oil quality and self-life of products processed using such oil.

In soybean, oleic fatty acid has been reported to exhibit a strong negative correlation with total oil content that is in agreement with the present study (Rani et al. 2007; Bachlava et al. 2008). The significant negative correlation between oleic acid and total oil suggests that it would be challenging to breed soybean varieties with high oleic fatty acid as well as high total oil content. A similar trend was observed between oleic acid and total protein, where there was a significant negative correlation. This implies that it is difficult to develop a soybean variety with high oleic acid and protein. The study suggests that the breeding program should aim at overcoming the negative correlation between oleic acid and total oil and total protein content using advanced techniques like genetic transformation.

\section{Conclusions}

Soybean genotypes originating from different sources have different nutritional properties like total protein, total oil, and fatty acids. Soybean genotypes from Japan had the highest protein content, while genotypes from the USA had the highest oil content. This study identified soybean genotypes with protein content up to $50.40 \%$ and oil content up to $24.23 \%$ that are way beyond the average nutritional properties of most soybean genotypes of $40 \%$ and $20 \%$, respectively. Such genotypes with elevated protein and oil content can be used by soybean breeders in Uganda and across the East African region to improve the protein and oil content of soybean varieties. The significant negative correlation of oleic acid with both total oil and total protein indicates that more efforts would be required to develop soybean varieties that contain high oleic acid as well as high total oil and total protein using conventional breeding. There is a need to explore other options of increasing oleic fatty acid content without altering the other nutritional traits.

\section{ACKNOWLEDGEMENTS}

This project was supported by the BecA-ILRI Hub through the Africa Biosciences Challenge Fund (ABCF) program. The ABCF Program is funded by the Australian Department for Foreign Affairs and Trade (DFAT) through the BecA-CSIRO partnership; the Syngenta Foundation for Sustainable Agriculture (SFSA); the Bill \& Melinda Gates Foundation (BMGF); the UK Department for International Development (DFID) and; the Swedish International Development Cooperation Agency (Sida).

\section{Author Contributions}

PT, TLO, JM, and NY: conceived and designed the experiments; TO, FN, JM, and NY: performed the experiments; TO, JPS: analyzed the data; TO, JPS: wrote the paper.

Conflict of interest: The authors declare no conflict of interest.

\section{References Références Referencias}

1. Ahire, Digambar Dadaji. 2012. Correlation Studies and Coefficient of Variation among Fatty Acids and Oil Quality Parameters in Soybean Mutants. Bioremediation, Biodiversity and Bioavailability 6: 107-112.

2. Alt, Jessie L., Walter R. Fehr, Grace A. Welke, and Devinder Sandhu. 2005. Phenotypic and Molecular Analysis of Oleate Content in the Mutant Soybean Line M23. Crop Science 45 (5): 1997-2000. doi:10.2135/cropsci2004.0664.

3. Bachlava, Eleni, Joseph W. Burton, Cavell Brownie, Sanbao Wang, Jérôme Auclair, and Andrea J. Cardinal. 2008. Heritability of Oleic Acid Content in

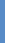

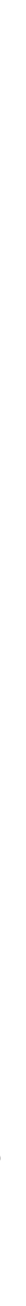


Soybean Seed Oil and Its Genetic Correlation with Fatty Acid and Agronomic Traits. Crop Science 48 (5): 1764-1772. doi:10.2135/cropsci2008.01.0049.

4. Baize, J. 1999. Global Soybean Meal Analysis Project. Conducted for the Quality Committee of the United Soybean Board: St. Louis, MO.

5. Bashaasha, Bernard. 1992. Soybean Research in Uganda.

6. Bligh E.G. and Dyer W.J. 1959. A Lipid Method of Total Lipid Extraction and Purification. Can. J. Biochem. 37: 911-917.

7. Cardinal, Andrea J., and Joseph W. Burton. 2007. Correlations between Palmitate Content and Agronomic Traits in Soybean Populations Segregating for the Fap1,Fapnc, and Fan Alleles. Crop Science $47 \quad$ (5): $1804-1812$. doi:10.2135/cropsci2006.09.0577.

8. Drago, Maria S., Roberto L., Dardo M. De Greef, and Rolando J. 2011. Use of Soybean in Cereal Based Food Formulation and Development of Nutritionally Improved Foods.Soybean and Nutrition. doi:10.5772/22088.

9. FAO. 2018. Online at http://www.fao.org/faostat. Accesseed on $6^{\text {th }}$ September, 2020.

10. FOSS, 2011. CyclotecTm 1093. User Manual 1000 8459 / Revision 4. www.foss.dk

11. Fehr, Walter R, and Earl G Hammond. 1998. Soybean Vegetable Oil Having Elevated Concentrations of Both Palmitic Acid and Stearic Acid.

12. Friedman M. and Brandon DL. 2001. Nutritional and Health Benefits of Soy Proteins. Journal of Agricultural and Food Chemistry 49 (3): 1069-1086. doi:10.1021/ jf0009246.

13. Fukushima D. 2011. Soy Proteins. In Handbook of Food Proteins, 210-232. Woodhead Publishing Series in Food Science, Technology and Nutrition.

14. Grieshop, Christine M., and George C. Fahey. 2001. Comparison of Quality Characteristics of Soybeans from Brazil, China, and the United States. Journal of Agricultural and Food Chemistry 49 (5): 2669-2673. doi:10.1021/jf0014009.

15. Karr-Lilienthal, Lisa K., Christine M. Grieshop, Neal R. Merchen, Donald C. Mahan, and George C. Fahey. 2004. Chemical Composition and Protein Quality Comparisons of Soybeans and Soybean Meals from Five Leading Soybean-Producing Countries. Journal of Agricultural and Food Chemistry 52 (20): 6193-6199. doi:10.1021/ jf049795+.

16. Lowry, O. H.; N. J.; Rosebrough, A. L.; Farr, and R. J. Randall. 1951. Protein Measurement with the Folin Phenol Reagent. Journal of Biological Chemistry. 193 (1): 265-275.

17. Maestri, Damián M., Diana O. Labuckas, Carlos A. Guzmán, and Laura M. Giorda. 1998. Correlation between Seed Size, Protein and Oil Contents, and
Fatty Acid Composition in Soybean Genotypes. Grasas y Aceites 49 (5-6): 450-453. doi:10.3989 /gya.1998.v49.i5-6.757.

18. Marega, Mario, Deonisio Destro, Lilian Azevedo Miranda, Wilma Aparecida Spinosa, Mercedes Concôrdia Carräo-Panizzi, and Ricardo Montalván. 2001. Relationships among Oil Content, Protein Content and Seed Size in Soybeans. Brazilian Archives of Biology and Technology 44 (1): 23-32. doi:10.1590/s1516-89132001000100004.

19. Miladinovic, M. Hrustic, M. Vidic, and J. 2011. Soybean. Institute of Field and Vegetable Crops, Novi Sad and Sojaprotein, Becej, AMB Graphics, Novi Sad, 510.

20. Pham, Toan Duc. 2011. Analyses of Genetic Diversity and Desirable Traits in Sesame (Sesamum Indicum L., Pedaliaceae): Implication for Breeding and Conservation.

21. Payne, RW., Harding, SA., Murray, DA., Soutar, DM., Baird, DB., Glaser, Al., Channing, IC., Welham, SJ., Gilmour, AR., Thompson, R., Webster, R. 2010. The Guide to GenStat Release 13, Part 2: Statistics. Hemel Hempstead UK: VSN International.

22. Qin, Peiyou, Wenwen Song, Xiushi Yang, Shi Sun, Xianrong Zhou, Ruping Yang, Nan Li, et al. 2014. Regional Distribution of Protein and Oil Compositions of Soybean Cultivars in China. Crop Science 54 (3): 1139-1146. doi:10.2135/ cropsci2013.05.0314.

23. Rahman, T. Anai, T. Kinoshita, and Y. Takagi. 2003. A Novel Soybean Germplasm with Elevated Saturated Fatty Acids. Crop Science.

24. Rani, Kumar V., Verma S. K., Shakya A. K., Hussain S.M., Content, and Chauhan G. S. 2007. Interrelationship between Oil Content and Fatty Acid Composition in Indian Soybean (Glycine Max) Cultivars. The Indian Journal of Agricultural Sciences, 59-62.

25. Rebetzke, G. J., V. R. Pantalone, J. W. Burton, T. E. Carter, and R. F. Wilson. 2001. Genetic Background and Environment Influence Palmitate Content of Soybean Seed Oil. Crop Science 41 (6): 1731-1736. doi:10.2135/cropsci2001.1731.

26. Singh, Preeti, R Kumar, S N Sabapathy, and A S Bawa. 2008. Functional and Edible Uses of Soy Protein Products.

27. Stoltzfus, W.R. Fehr, G.A Welke, and D.L. 2000. Relationship of Elevated Palmitate to Soybean Seed Traits. Crop Science, 52-54.

28. Tukamuhabwa P., Obua T., Namara N. Okii D., Kabayi P., Yiga G. 2019. Soybean Research and Development in Uganda: Highlights 2002-2018. Makerere University, Kampala, Uganda.

29. Tukamuhabwa P and Oloka HK. 2016. Soybean Research and Development in Uganda: A Case of Paradigm Shift in an African University.Makerere University, Kampala, Uganda. 